Gerontology 1990;36:I-VI

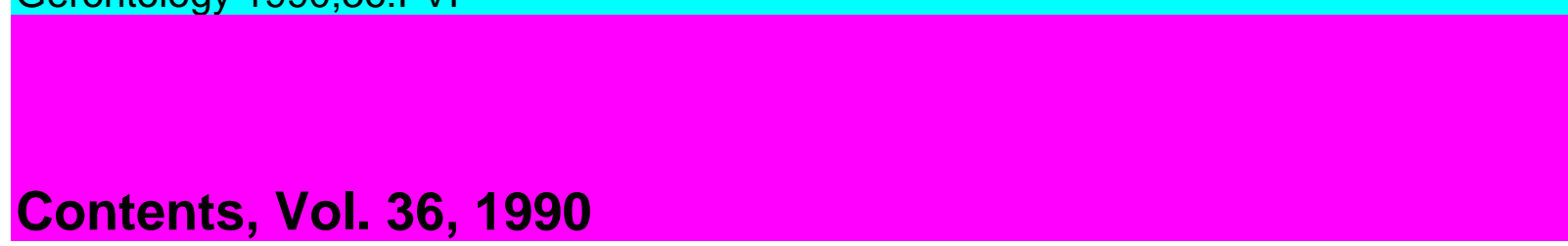

\title{
Vol. 36, 1990
}

Gerontology

International Journal of Experimental and Clinical Gerontology Organ of the International Association of Gerontology (IAG)

Founded 1957 by F. Verzàr as 'Gerontologia', merged 1975 with 'Gerontologia Clinica',

founded 1959 by E. Woodford-Williams and A.N. Exton-Smith

Managing Editor

Editorial Board

H.P. von Hahn, Basel

Experimental Section

Clinical Section

P.S. Chen, Zurich

A.R. Boobis, London

Experimental Section Editor

Y. Courtois, Paris

J. Brocklehurst, Manchester
A.N. Davison, London
C. Bulpitt, London
Clinical Section Editor

L.M. Franks, London

J. Cassar, Middlesex

J. Andrews, London

V.V. Frolkis, Kiev

I. Gray, Coventry

Editor for North America M.M.B. Kay, Temple,

Tex.

D. Gershon, Haifa

D.A. Hall, Leeds 
F.A. Lints, Louvain-la-Neuve

R. Harris, Albany, N.Y. B. Isaacs, Birmingham J. Knox, Hull

Editor for the IAG

A. Macieira-Coelho, Villejuif

J. Marshall, London

E.W. Busse, Durham,

N.C.

T. Makinodan, Los Angeles, Calif.

W. Meier-Ruge, Basel

J.F. Nelson, Montreal

Catherine Nissen, Basel

D. Platt, Erlangen-Nürnberg

L. Robert, Créteil

F. Post, London

W\&/

Daniela Schlettwein-Gsell, Basel

N.W. Shock, Baltimore, Md.

\section{AQQП\&-}

H. Thomae, Bonn

\section{$\mathrm{V} / \Psi$}

Patricia D. Wilson, Piscataway, N J.

\section{KAHGER}

S. Karger - Medical and Scientific Publishers

Basel · München · Paris · London · New York $\cdot$ New Delhi $\cdot$ Bangkok $\cdot$ Singapore $\cdot$ Tokyo $\cdot$

Sydney

Drug Dosage

The authors and the publisher have exerted every effort to ensure that drug selection and dosage set forth in this text are in accord with current recommendations and practice at the time of publication. However, in view of ongoing research, changes in government regulations, and the constant flow of information relating to drug therapy and drug reactions, the reader is urged to check the package insert for each drug for any change in indications and dosage and for added warnings and precautions. This is particularly important when the recommended agent is a new and/or infrequently employed drug.

All rights reserved. 
No part of this publication may be translated into other languages, reproduced or utilized in any form or by any means, electronic or mechanical, including photocopying, recording, microcopying, or by any information storage and retrieval system, without permission in writing from the publisher or, in the case of photocopying, direct payment of a specified fee to the Copyright Clearance Center (see 'Information for Readers and Subscribers').

(C) Copyright 1990 by

S. Karger AG, P.O. Box, CH-4009 Basel (Switzerland) Printed in Switzerland by Thür AG Offsetdruck, Pratteln

Contents Vol. 36,1990

No. 1 Editorial

Nathan W. Shock 1

Experimental Section

In vitro Assessment of Chemotaxis by Peripheral Blood Neutrophils from Adult and Senes cent C57BL/6 Mice: Correlation with in vivo Responses to Pulmonary Infection with Type 3 Streptococcus pneumoniae

Esposito, A.L.; Poirier, W.J.; Clark, C.A 2

Effect of Malonate and p-Chlorophenoxy Acetic Acid on Hepatic Succinic Dehydrogenase Activity of Ageing Lizards

Jena, B.S.; Patnaik, B.K 12

Decreased Plasma Taurine in Aged Rats

Wallace, D.R.; Dawson, R., Jr 19

Skin Thickness Changes in Normal Aging Skin

Branchet, M.C.; Boisnic, S.; Frances, C; Robert, A.M 28

Changes in Female Sexual Behavior of Old Female Rats: Comparison between Exit Method and Non-Exit Method

Yang, F.J.; Peng, M.T 36

Clinical Section

Stability of Cerebral Blood Flow and Oxygen Metabolism during Normal Aging

Itoh, M.; Hatazawa, J.; Miyazawa, H.; Matsui, H.; Meguro, K.; Yanai, K.; Kubota, K.;

Watanuki, S.; Ido, T.; Matsuzawa, T 43

Intermittent Dobutamine Infusion in Severe Chronic Heart Failure in Elderly Patients

Van den Brande, P.; Van Mieghem, W.; Demendts, M

Biochemical Predictors for Osteoporotic Fractures in Elderly Chinese - A Longitudinal Study

Woo, J.; Lau, E.; Swaminathan, R.; Pang, C.P.; MacDonald, D 55

Book Review 59

Announcement 60

No. 2 Experimental Section

RNA Synthesis by Nuclei and Chromatin Isolated from Adult and Senescent Wistar Rat Liver

Park, G.H.; Buetow, D.E 61

RNA Synthesis by Hepatocytes Isolated from Adult and Senescent Wistar Rat Liver

Park, G.H.; Buetow, D.E 76

Contents

Debate

Does Progeria Provide the Best Model of Accelerated Ageing in Humans? 
Mills, R.G.; Weiss, A.S 84

Dietary Restriction - A Procedure with Undefined Goal: A Critical Review of Two Recent

Books

Bellamy, D 99

Clinical Section

Autoantibodies of Systemic Rheumatic Diseases in the Healthy Elderly

Ruffatti, A.; Rossi, L.; Calligaro, A.; Del Ross, T.; Lagni, M.; Marson, P.; Todesco, S. 104

Treadmill Exercise Electrocardiography in the Elderly with Physical Impairments

Thompson, R.F.; Crist, D.M.; Osborn, L.A.; Atterbom, H.A112

Book Reviews 119

Experimental Section

Ageing and Temperature Effects on the Tumour Development in Drosophila melanogaster

Females

Kosuda, K 121

Variations in the Life Span, Enzymes and Lipid Peroxide Levels in Ageing Caryedon serratus (Coleoptera: Bruchidae)

Garg, S.K.; Mahajan, S.; Sharma, S.P 126

Debate

On the Strategy of Directed Assembly and Its Relevance to Ageing

Wagner, A.P 132

Clinical Section

Longitudinal Study of Thyroid Function in Acutely Ill Elderly Patients Using a Sensitive

TSH Assay-Defer Testing until Recovery

Bhakri, H.L.; Fisher, R.; Khadri, A.; MacMahon, D.G 140

Labyrinth Learning Impairment in Patients with Early Symptoms of Presenile Dementia

Mueller, G.; Richter, R.A.; Weisbrod, S.; Klingberg, F 145

Medical Correlates of Agitation in Nursing Home Residents

Cohen-Mansfield, J.; Billig, N.; Lipson, S.; Rosenthal, A.S.; Pawlson, L.G 150

Features of Multiple Sclerosis in Older Patients in South Wales

White, A.D.; Swingler, R.J.; Compston, D.A.S 159

Monokine Production by Malnourished Nursing Home Patients

Bradley, S.F.; Vibhagool, A.; Fabrick, S.; Terpenning, M.S.; Kauffman, C.A 165

Critical Review

Hypernatraemia in the Elderly Patient

Solomon, L.R.; Lye, M 171

Letter to the Editor

Tobis, J.S 180

Book Reviews $\quad 181$

Announcement $\quad 184$

Contents V

No. 4 Experimental Section

Influence of Aging on Ethanol and Acetaldehyde Oxidation in Female Rat Liver

Rikans, L.E.; Snowden, CD.; Moore, D.R 185

Salivary Amylase Activity of the Aged

Wang, C.-H.; Woolfolk, C.A 194

Clinical Section 
Primitive Reflexes and MRI Findings, Cerebral Blood Flow in Normal Elderly

Kobayashi, S.; Yamaguchi, S.; Okada, K.; Yamashita, K 200

Cardiac Findings in the Very Elderly: Analysis of Echocardiography in Fifty-Eight Nona genarians

Tunick, P.A.; Freedberg, R.S.; Kronzon, 1207

Low Serum Ionized to Total Calcium Ratio: Association with Geriatric Diabetes mellitus and with Other Cardiovascular Risk Factors?

Sorva, A.; Tilvis, R.S 213

Analysis of Cutaneous Delayed-Type Hypersensitivity Reaction and T Cell Proliferative Response in Elderly Nursing Home Patients: An Approach to Identifying Immunodefi-cient Patients

Castle, S.C.; Norman, D.C.; Perls, T.T.; Chang, M.-P.; Yoshikawa, T.T.; Makino-

dan, $\mathrm{T} 218$

Critical Review

Should Medical Screening of the Elderly Population Be Promoted?

Bulpitt, C.J.; Benos, A.S.; Nicholl, C.G.; Fletcher, A.E 230

Book Reviews 246

Announcement 248

No. 5-6 Experimental Section

Comparison of the Production of Cyclic AMP in Response to Parathyroid Hormone in

Fibroblasts from Aged Subjects and Young Subjects: Lack of an Age-Dependent

Decrease

Morimoto, S.; Takamoto, S.; Imanaka, S.; Kitano, S.; Miyashita, Y.; Fukuo, K.; Koh, E.;

Ogihara, T 249

Spontaneous Activity Level and Life Span in Rotifers: Lack of Support for the Rate of

Living Theory

Enesco, H.E.; McTavish, A.; Garberi, R 256

Age-Related Responses of Hepatic Glucose Uptake to Starvation and Cold Stress in Male Garden Lizards

Jena, B.S.; Patnaik, B.K 262

Involvement of Lipoproteins in Suppression of Interleukin 2-Dependent Cell Proliferation by Sera from Aged Humans

Ohtsuka, Y.; Kobayashi, K.; Hirano, T.; Furukawa, S.; Nagano, S.; Takahashi, T. . 268 Age-

Related Changes of the Human Skin Surface Microrelief

Vörös, E.; Robert, C; Robert, A.M 276

Influence of Age on the Thyroid Hormone-Induced Up-Regulation of ß-Adrenoceptors in

Mouse Brain Cortex

Viticchi, C; Grinta, R.; Piantanelli, L 286

VI Contents

Molecular Mapping of the Active Site of an Aging Antigen: Senescent Cell Antigen Requires

Lysine(s) for Antigenicity and Is Located on an Anion-Binding Segment of Band 3

Membrane Transport Protein

Kay, M.M.B.; Lin, F 293

Blood Activity of $\mathrm{Cu} / \mathrm{Zn}$ Superoxide Dismutase, Glutathione Peroxidase and Catalase in Alzheimer's Disease: A Case-Control Study

Perrin, R.; Briançon, S.; Jeandel, C; Artur, Y.; Minn, A.; Penin, F.; Siest, G 
Debate

Does a Centralized Clock for Ageing Exist?

Kloeden, P.E.; Rössler, R.; Rössler, O.E 314

Lamarckism and Ageing

Jablonka, E.; Lamb, M.J 323

Clinical Section

Comparative Analysis of Cardiopulmonary Responses during Dynamic Exercise with Wrist

Weights in the Elderly versus Young Hypertensic Responders

Sagiv, M.; Goldhammer, E.; Pollock, M.L.; Graves, J.E.; Schneewiss, A.; Ben-Sira, D. 333

Prevalence of Parkinson's Disease in Izumo City, Japan

Okada, K.; Kobayashi, S.; Tsunematsu, T 340

Urinary IgG and IgA Antibodies in Elderly Individuals with Bacteriuria

Nicolle, L.E.; Brunka, J 345

Twenty-Four-Hour Secretory Pattern of Vasoactive Intestinal Polypeptide in the Elderly

Rolandi, E.; Franceschmi, R.; Cataldi, A.; Barreca, T 356

Computerized Tomography with Longitudinal Follow-Up of Brain Atrophy in Patients with Parkinson's Disease

Kitani, M.; Kobayashi, S.; Yamaguchi, S 361

Author Index 369

Subject Index 371

Suppl. 1 The First Symposium by the 6 Winners of the Grants from Sandoz Foundation for Gerontological Research

Nagoya, Japan, November 13, 1989 Chairman: H. Orimo, Tokyo

Suppl. 2 Management of Urinary Incontinence in the Community

Held during the World Congress of the XIV. Meeting of the International Association

of Gerontology, June 18-23, 1989

Acapulco, Mexico

Guest Editor: J.C. Brocklehurst, Manchester, UK 